\title{
Human Settlement Dynamics in the Bamenda III Municipality, North West Region, Cameroon
}

\author{
Lawrence Akei MBANGA ${ }^{1}$ \\ ${ }^{1}$ The University of Bamenda, Faculty of Arts, Department of Geography and Planning, Bamenda, CAMEROON \\ E-mail: mbangalaw@yahoo.com \\ DOI: 10.24193/JSSP.2018.1.05 \\ https://doi.org/10.24193/JSSP.2018.1.05
}

\begin{abstract}
A B S T R A C T
Every human settlement, from its occupation by a pioneer population continues to undergo a process of dynamism which is the result of socio economic and dynamic factors operating at the local, national and global levels. The urban metabolism model shows clearly that human settlements are the quality outputs of the transformation of inputs by an urban area through a metabolic process. This study seeks to bring to focus the drivers of human settlement dynamics in Bamenda 3, the manifestation of the dynamics and the functional evolution. The study made used of secondary data and information from published and unpublished sources. Landsat images of 1989 , 1999 and 2015 were used to analyze dynamics in human settlement. Field survey was carried out. The results show multiple drivers of human settlement dynamism associated with population growth. Human settlement dynamics from 1989, 1999 and 2015 show an evolution in surface area with that of other uses like agriculture reducing. Multiple functions and network infrastructure evolve with human settlement. In the Bamenda 3 municipality, the dynamics of human settlements was slow but constant up to the year 2007. In 2007, the Bamenda III municipality was created. It serves as a gateway to the administrative divisions of Boyo, Ngoketunjia, Bui and Donga Mantung and an important transit for passengers and goods to and from the North West Region. It is crossed by a major road and has several education establishments. It attracts every population age group and of various professions such as students and other stakeholders. Farmland is gradually reducing since 1989, transformed continuously into human settlements. This expansion is more of the informal due to a weak implementation of legislation and a weak control mechanism. There is need for a strict control mechanism to reduce informal settlements.
\end{abstract}

\section{INTRODUCTION}

Human settlements appear to be the most dynamic human elements over the earth's surface [1]. Settlements are the most visible signs that human culture has imposed on the natural world [2]. This dynamism is propelled by a rapid urbanization in the world which is the result of an ever increasing population. Globally, since 1950, the process of urbanization has been faster with more than half of the world's population now living in urban areas with about $54.5 \%$ in 2016 as compared to $37.9 \%$ in 1976 [3]. The present dynamic state of human settlements in the world is the outcome of urbanization. A broader socio economic and political process in the world shall affect human settlements at all levels; global, national and local. About $52 \%$ of the developing world's population shall be living in cities by 2020. Demographic explosion in Africa and Asia is certain. The success or failures in urban development policies shall be observed in the physical structure of human settlements and their nature; formal or informal [4].

In the developing world, the Latin American and the Caribbean areas are considered as the most urbanized. Argentina, Uruguay and Venezuela are at an advanced stage of urbanization. Human settlement dynamics has accompanied urbanization through expansion into new areas and the densification of the 
core areas. Unfortunately, the region's human settlement dynamics is impacted by an unplanned urbanization. Integrated urban areas upgrading programmes with new policies for social housing have been put in place in Chile, Colombia and Costa Rica to improve on informal settlements. There is need for sustainable cities with sustainable human settlements [5].

Human settlements grow into formal and informal settlements. This growth which has led to the emergence of hamlets and villages which have become towns and cities, has led to well-planned and organized settlements in some areas and where there has been lack of planning, it has led to the creation of informal settlements with attendant problems. Some parts of human settlements are recognized by public authorities. They are formal. The informal human settlements are not recognized by public authorities. They are spontaneous, disorderly and unplanned. This sore sight of human settlements is common in developing countries. There are mixed informal and formal settlements in several cities in Africa. Settlements constructed without any legal basis, built on inappropriate sites or on land destined for other functions are considered as illegal. There is need for special policies to solve this problem such as reshaping human settlement legality for the poor and urban renewal through upgrading of informal settlements [6]. There are about 1.2 million households in South Africa currently living in informal settlements under very precarious conditions and this poses serious threat to the health, the safety and the security of the population. A government programme in 2004 was put in place to upgrade and eradicate all informal settlements by 2014 in South Africa. Despite a comprehensive national legislation and policy framework, there are still issues of inconsistencies, tensions and problems [7].

The evolution of settlements throughout Africa from tiny hamlets to larger settlements has led to an urban population in Africa of about 40\%. The urban areas have the highest concentration and the most dynamic growth in human settlements. Cities have attracted and will continue to attract population due to the wide range of opportunities for economic advancement that they provide. The quality of service delivery, resources and economic development in an urban area is determined by the interconnectivity and spatial distribution of its human settlements. Population statistics can be used to quantify settlement patterns. Several regions in Africa have high population densities. Travel time between and in urban areas are determined by the population density and human settlements. Human settlement distribution, interconnectivity and accessibility are important factors to understand socio economic and political issues for urban development [8]. Two studies on human settlements in Nigeria were very revealing. The Esan area of Edo state, in Nigeria is an example of human settlement evolution from tiny hamlets to larger settlements. The Esan people migrated from Benin Kingdom in the $14^{\text {th }}$ Century and created tiny but dispersed hamlets in the Esan colony. They later regrouped into larger settlements due to slave raiders, illnesses, hazards and wild animal attacks. This later led to the regrouping of villages especially the Egwaks. These settlements are rapidly expanding presently due to high socio-economic development. Human settlements in Ilorin South LGA of Kwara State, Nigeria are endowed with different functions and are arranged in a hierarchy of first order, second order and third order. Several factors influence the implantation and distribution of settlements. They include; relief, climate, vegetation, political, socio economic, historical and mythical factors. These factors impact the degree of concentration of people, the extent of planning for the people and the attainment which varies from one settlement to another as well as settlements variation in terms of their functional attributes [9], [10].

Hamlets become villages, villages become towns, towns become cities, and several cities coalesce into larger conurbations and agglomerations. This dynamism is taking place in the developed as well as the developing world with varying intensities characterized by planned and unplanned settlements. Most unplanned human settlements are found in towns of the developing world where due to poverty, there is very little or no respect of legislation on habitat construction. An example is in Cameroon where unplanned human settlements are far more than planned human settlements in the urban areas.

In two separate studies on human settlement dynamics and patterns in two coastal areas, Port Harcourt, Nigeria, and Ningbo, China, population growth was identified as the main driver. Population increase in Port Harcourt and in Ningbo has led to an evolution in land use for settlement and socio-economic infrastructures. Their coastal nature, potential vulnerability and specific challenges made the areas to be focal zones for specific land use, especially human settlements. Informal and formal as well as in situ expansion and enclave expansion characterized human settlement dynamics in both areas. Port Harcourt is one of Nigeria's fastest growing cities and has a growing informal human settlement sector while Ningbo is the second largest growing city in Zhejiang Province in China with government dominated settlement development [11], [12]. The development of sustainable human settlements is one of the major development challenges of the South African government. The South African government strives for sustainable cities with all the social, material, organizational, spiritual and cultural elements to sustain it [13].

Human settlements dynamism is not without impacts. The most important impact is its imprints on 
the environment. Human settlements are among the most important drivers of environmental change. There exists a complex relationship which is continuously changing. The natural environment provides the basic elements that human beings need to survive like land and water. The global impact of human settlements on the world's natural environment shows an increase with population growth, density, settlement expansion, economic growth and increased consumption. Land transformation, degradation and pollution are identified as the imprints [14].

The first objective of this study was to bring to focus the drivers of human settlement dynamics in Bamenda 3. After identifying, presenting and analyzing the drivers, the second objective of the study was to study the phases and manifestation of human settlement dynamics. The third objective of the study was to study the evolution in the functions offered in the study area which is linked to human settlement dynamics.

\section{CONCEPT}

The concept of human settlement has evolved over the years. It has become a strategy for socio economic development in the framework of formulating global shelter strategies. There is a consensus that human settlements are not only about spatial aspects but also about the physical manifestation of economic and social activity. Settlements remain a critical base for socio economic development in that "places where people can live, learn and work in conditions of safety comfort and efficiency are a fundamental and elementary need" [9].

Settlements are the distribution of buildings by which people attach themselves to land. Settlement is any place where humans live and includes hamlets, villages, towns, cities and megacities. Buildings are constructed for shelter and for several other socio economic uses [11]

People seldom live in isolation, most reside in settlements which vary greatly in size, composition, location, arrangement and function [1]. Human settlements serve as a base for economic development and are the physical expression of the economic and social activity, are places with spatial dimensions, that is, where people live, learn and work. Human settlements are a cluster of dwellings of any type or size where human beings live.

Urban areas can be considered as a special ecosystem having reduced space, multiple communities but under the domination of human beings who induce changes through several activities like the construction of human settlements. The Urban Metabolism Model was developed in the mid 1960's by Wolman, improved by Newman et al in 1996 to become the Extended Urban Metabolic Model. A New Urban Metabolic Model was produced by making inputs into the other models by A. Costa who has integrated sustainability principles and control mechanisms into urban growth. According to this model, institutional activities like territorial planning, urban governance, urban renewal and other development policies must be included to well planned, implement and control the expansion of urban areas in important sectors like human settlement. The inputs are the resources like water, land and building materials while the physical components are outputs which are settlements, social and technical infrastructures like schools, hospitals, sports and cultural facilities, welfare centers and roads network. In application of this model, every area today can be considered as a "metabolism". The population inputs on the area by exploiting its resources such as energy, water and materials. The objective is to transform the area into a habitable space for human wellbeing and prosperity. Though this leads to good quality outputs, it also leads to negative outputs like waste production, air and water pollution and environmental degradation. Institutions like the municipal council put in place planning and control mechanisms for an orderly evolution of the area [15]. The Bamenda III Municipality which is the Bamenda III Sub Divisional like every other area in the world operates in this metabolic manner.

Bamenda III is located between latitude 6' 15 and $6{ }^{\prime} 25 \mathrm{~N}$ and Longitude 10'02 and 10'15E of Green which Meridian (Fig. 1).

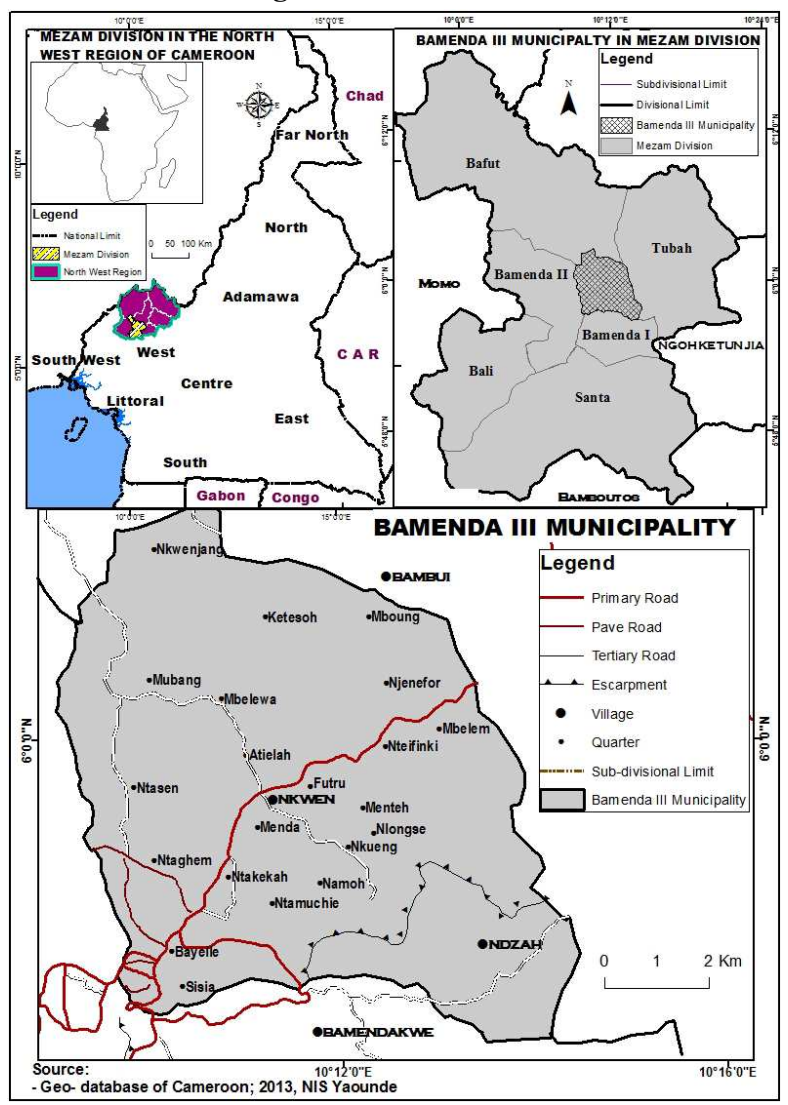

Fig. 1. Location of Bamenda III Municipality in Mezam Division, North West Region, Cameroon. 
The Sub Division is the gateway to and from Boyo, Ngoketunja, Bui and Donga Mantung Divisions. It is bounded by Tubah Sub Divisional Council to the West, Bamenda I Sub-Divisional Council to the North, Bamenda II Sub-Divisional Council to the East and Bafut Sub Divisional Council to the South. It has a total surface area of $67.9 \mathrm{~km}^{2}$ and a population estimated at 150,000 inhabitants. Two autonomous villages, Nkwen and Ndzah make up the Bamenda III Municipality. There are 46 quarters in Nkwen and 9 in Ndzah village.

\section{METHODOLOGY}

A selective review of published and unpublished documents on human settlement dynamism in several parts of the world was carried out. The Bamenda III Council Development Plan provided background information on the study area as well as a vision for the future.

Dissertations, thesis and institutional reports all link to the theme were consulted in the University of Bamenda. They all provided secondary data for the study. A field survey was carried out in the study area. Through direct observation, interview of resource persons and the administration of questionnaires, primary data was collected and analyzed for this study. The field survey consisted of several field trips for field observation in Bamenda III in 2015 and 2016 to observe realties in human settlement dynamics in the various quarters. It led to an identification and understanding of the functional codes in the study area.

The Mayor of Bamenda III Municipality, the Delegate for Town Planning and Housing, several Councilors, the Traditional Ruler and 10 Quarter Heads were interviewed on the evolution of human settlements in the study area. For each resource person, an interview guide was prepared since they play different specific roles in human settlement evolution. The Quarter Heads were chosen based on the intensity of human settlement expansion in their quarters. The traditional ruler is the custodian of tradition and the land and impacts the trend of human settlement in his village.

A number of 75 questionnaires were administered to a target population. Household's heads, businessmen, tenants, private education and health officials of the active and old age gropes were selected through systematic sampling for the administration of the questionnaires. In order to well analyze and illustrate the different phases of manifestation of human settlement dynamics in the study area, Landsat images for 1989, 1999 and 2015 were downloaded from USGS and processed using ArcGIS 10.1.

The analysis permitted the calculation of the various land use surface area changes for settlement, farmland, forest and grassland in 1989, 1999 and 2015 respectively.

\section{RESULTS AND DISCUSSION}

\subsection{Drivers of human settlement dynamics in the Bamenda III municipality}

\subsubsection{A constantly growing population}

The Bamenda III Municipality was carved out of the Bamenda City Council in 2007 and is made up of the villages of Nkwen and Ndzah. The population of these villages had been at a constant increase for the past one and a half decade (Table 1 ).

Table. 1. Population evolution in the Bamenda III Municipality between 1999 and 2015.

\begin{tabular}{l|r|r}
\hline Year & Population & Absolute growth \\
\hline 2015 & 150,000 & 9,000 \\
2014 & 141,000 & 8,460 \\
2013 & 132,540 & 7,952 \\
2012 & 124,528 & 7,475 \\
2011 & 117,113 & 7,027 \\
2010 & 110,086 & 6,605 \\
2009 & 103,481 & 6,209 \\
2008 & 97,272 & 5,836 \\
2007 & 91,436 & 5,486 \\
2006 & 85,950 & 5,157 \\
2005 & 80,793 & 4,848 \\
2004 & 75,945 & 4,557 \\
2003 & 71,388 & 4,283 \\
2002 & 67,105 & 4,026 \\
2001 & 63,079 & 3,785 \\
2000 & 59,294 & 3,558 \\
1999 & 55,736 & - \\
\hline \multicolumn{2}{|c|}{ Source: [16]. } & \\
\hline
\end{tabular}

Since the year 1999 and confirmed by the National Demographic and Housing Census of 2005, there has been a population increase of about $6 \%$ per annum. The constant population growth is caused by a very positive natural balance and a very positive net migration. The most dominant population is the youth and serves as a pool of potential human resources for the council area. There are more women than men in Nkwen and Ndzah villages that make up the municipality. There is an increase in birth rate and a decrease in death rate by about $3 \%$, probably due to increased access to/and improvement in health care delivery, a gradual shift from local health care practices and improvement in nutrition. However, much still has to be to done to improve on the standard of living of the population.

The population of the Bamenda III municipality is also constantly increasing as a result of a very positive net migration. The municipality serves as a gateway to four administrative divisions of the North West Region; Boyo, Ngoketunjia, Bui and Donga Mantung. The people of these areas migrate easily and settle in this municipality. Nevertheless, the leading group is from Mezam division where the municipality is 
administratively located. Several workers and students live in the Bamenda III municipality and commute daily to work and/or study in the University of Bamenda created five years ago and located in the neighboring Tubah municipality. There are also French speaking Cameroonians from the neighboring West region as well as some Nigerians (Fig. 2).

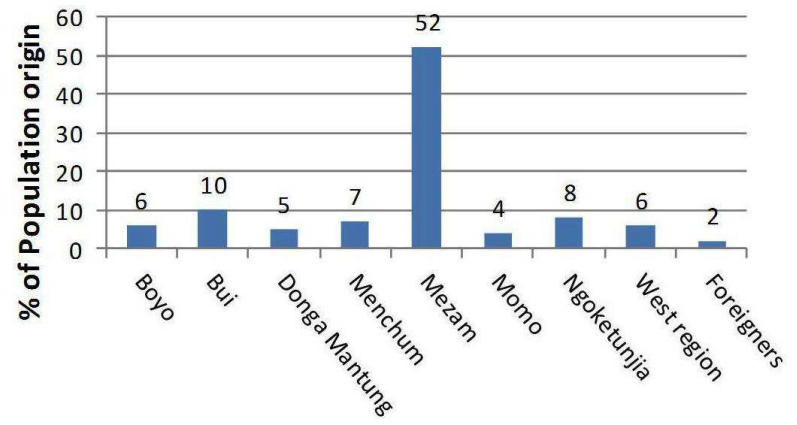

Fig. 2. Diverse origin of the population of Bamenda III Municipality.

The very enterprising population from the West region of Cameroon known as the "Bamieleke" makes up a significant part of national migrants into the area due to proximity. They invest in housing construction, especially with several floors to let. They operate most big businesses and several small and medium size enterprises in the area like travel agencies and building materials construction, thus contributing to human settlement evolution.

\subsubsection{A weak land tenure policy}

In Cameroon, traditional and modern rights to land ownership prevail and overlap. Traditional land ownership rights were instituted by traditional authorities who are the custodians of the land over which they rule. Though the traditional ruler is the overall manager of land, the land in a village for example in Cameroon is own by the entire village community. The traditional ruler shares the land to the several clans that make up the village community. The clan head in turn shares the land to the members of his small community. The traditional ruler can also identify any portion of the land for the construction of a social amenity like schools and hospitals. The land can also be handed as a gift to the churches. Though this may vary from one village community to another, the situation described here is what prevails in the Nkwen and Ndzah villages that make up the Bamenda III municipality. Traditionally, individuals acquire land through inheritance from parents. Presently only about 10\% have acquired land in Bamenda III through inheritance, $80.9 \%$ through buying, $6.4 \%$ as a gift and $2.1 \%$ through a mortgage [16]. Bamenda III municipality is an administrative area in the Bamenda City Council and so it is opened to immigrants from the six other administrative divisions of the North West region of Cameroon and even to foreigners. The notion of immigrant or outsider in this community is very strong in land affairs and the ceding of traditional land to an immigrant is a very simple process especially if the immigrant can afford it. This explains the high percentage of land acquisition by buying. According to the 1974 law, land is divided into three categories in Cameroon; registered land belonging to the State, registered private land (with a title deed) and national land (former traditional lands which are neither private nor belong to the State).

The Ministry of State Property, Surveys and Land Tenure is responsible for managing the land tenure procedures in respect of Ordinance No 74-1 of 67-74 to establish rules governing land tenure in Cameroon. Ordinance $74-1$ is related to private and public property and national lands while the Ordinance 74-2 is related to public domain in Cameroon. They are usually presented together to explain the land tenure system which is based on land registration. It states clearly that all privately-owned land must be registered because all unregistered land is deemed to be either public land held by the state on behalf of the public or national land, i.e. all unoccupied and under traditional law lands. The limited implementation capacities of the Ministry of State Property, Surveys and Land Tenure have not allowed for effective enforcement of these laws. Like elsewhere in Cameroon, in Bamenda III Municipality only a small number of lands have ever been registered. Two important documents to be acquired are the Building Permit and the Land Certificate. This renders the construction in terms of shelter formal or authorized. The records of these documents show an increasing evolving trend (Table 2).

Table 2. Evolution in building permit and land certificate issued in Bamenda III, 199-2015.

\begin{tabular}{|l|r|r|r|r|r|r|}
\hline Year & \multicolumn{1}{|c|}{1999} & \multicolumn{1}{|c|}{2000} & $\mathbf{2 0 0 1}$ & $\mathbf{2 0 0 2}$ & $\mathbf{2 0 0 3}$ & $\mathbf{2 0 0 4}$ \\
\hline BP & 36 & 64 & 74 & 104 & 81 & 64 \\
\hline LC & - & - & - & - & - & - \\
\hline Year & 2005 & 2006 & 2007 & $\mathbf{2 0 0 8}$ & $\mathbf{2 0 0 9}$ & $\mathbf{2 0 1 0}$ \\
\hline BP & 86 & - & - & - & - & - \\
\hline LC & - & 74 & 149 & 172 & 176 & 145 \\
\hline Year & 2011 & 2012 & 2013 & 2014 & 2015 & \\
\hline BP & - & - & - & - & - & - \\
\hline LC & 151 & 176 & 196 & 213 & 256 & - \\
\hline
\end{tabular}
Source: [17], [18].

Field observations show that about 300 new houses were constructed in Bamenda III municipality in 2015 and this is expected to be higher by the end of 2016. Only 256 Building Permits were issued in 2015 as well as 41 Land Certificates. The records are difficult to exploit because Building Permits issued before 2007, (The year the Bamenda III Municipality was carved out of the Bamenda City Council) were issued under the Bamenda City Council. Since 2007, 2000 Building 
Permits have been issued as a whole for the Bamenda III Municipality alone. Due to the costly nature to obtain a Building Permit and the very long, expensive and difficult procedure to obtain a Land Certificate, it is very difficult to have correct statistics on settlement evolution in this municipality. It is estimated that one out of every ten settlements is authorized. The weak land tenure policy is a driving force for settlement expansion in Bamenda III Municipality. It allows for formal and informal settlements to be constructed. There is a very weak control mechanism that paves the way for the proliferation of unplanned settlement.

\subsubsection{The existence of multiple stakeholders on land development}

The dynamism of human settlement in the Bamenda III Municipality is also linked to the multiple stakeholders involved in land development. The first stakeholder is the state, the owner of all land in Cameroon. The take off period for rapid and dense settlement evolution in the Bamenda III Municipality is 2007. This is when the state uplifted the status of Nkwen and Ndzah villages to a Sub Division, the third administrative category unit in Cameroon. The uplifting of the administrative status permitted the area to have a municipality, the Bamenda III Municipality, the local institution for development in Cameroon. This was a spring board for settlement evolution as the area became administrative and municipally independent. It led to an influx of state officials to work in the newly created Sub Divisional Delegations of various Ministries. Several public secondary schools were created for the primary and secondary levels leading to settlement expansion to quarters like Atielah.

The second stakeholder is the traditional authorities in Nkwen and Ndzah villages who have made the procedure of settlement of immigrants flexible. Any non-indigene who affords a land area in Bamenda III Municipality has to provide the stable food to the landlord as well as a bag of salt and 20 liters of palm oil. The quantity depends on the size of the land. A list of items is to be provided to the quarter meeting after which inspection of the land is done. This procedure permits the immigrant to be accepted and integrated into the quarter. Only after these procedures can an immigrant carry out any construction work, whether authorized or not by the state authorities.

Religious bodies have contributed enormously to settlement dynamics in the Bamenda III Municipality. The Catholic, Presbyterian and Baptist Churches are the leading religious bodies in this area. A small Moslem community exists as well as several Pentecostal Churches of minor influence. Found in a highly Christianized region, the old tradition of preferred settlement around churches by Christians led to the rapid development of quarters like Bayelle, Futru, Mbelem and Menteh for the Catholics, Ntassen, 52
Mugheb, Ntaghem and Menda for the Presbyterians and Menda for the Baptist. The Catholics, Presbyterians and Baptist Churches have created schools and colleges in several quarters whose direct impact has been the attraction of the population to settle in such areas. A good example is the Presbyterian Secondary School in Ntassen and the St Paul Catholic College.

Private entrepreneurs are amongst the multiple stakeholders contributing to the dynamism of settlement in the Bamenda III Municipality. The Bamenda III Municipality is becoming self-sufficient in terms of the provision of certain services like education thanks to private entrepreneurs. Though there are state owned schools from the nursery to the secondary and high school levels, the private sector is leading in the provision of education services. From pre-nursery, nursery, primary, secondary, high schools and the university, private entrepreneurs have carried out heavy investments in Bamenda III Municipality such that a child can complete the pre nursery to university education without leaving Bamenda III Municipality. EduCare for example provides pre nursery, nursery and primary education. Starlight College provides complete general and commercial education. The Bamenda University of Science and Technology, the National Polytechnic, the St Louis Medical Higher Institute and the FONAB Higher Institute are the biggest higher education institution in the Bamenda City Council and found in Bamenda III Municipality. An accompanying element around these institutions is the construction of students' hostels which is one of the major elements of settlement dynamism in Bamenda III. The creation of secondary and high schools have contributed to the full dynamism of human settlement in Bamenda III municipality. It has attracted indigenes and nonindigenes, economic operators and students to this area.

\subsubsection{Other drivers of settlement dynamics in Bamenda III}

These drivers affect the dynamics of settlements in Bamenda III as a surface. They are; the price of land, communication potential, access to facilities and services and the geographical risk and will be analyzed together. As a single driver, none of these will have a high impact on the dynamics of settlements in this area. The price of land alone will not have a significant impact on settlement dynamics. But together, they have a strong pull force on the constantly increasing population which is made up of migrants also.

Between 1980 and 1995, the average price of land was 1500FCFA (2.72 USD) per square meter in the urban fringe area and already at 6.00o FCFA (10.9 USD) in the core area. The purely urban during this period was limited to the South Western part of 
Bamenda III. About 2/3 of the area was purely rural. The urban part had a high communication potential with a good interconnectivity and accessibility. The rural part of Bamenda III had no major road, no secondary or high school nor university, no police station, no market and had a much reduced interconnectivity and accessibility. There was little interest on land occupation in the rural urban fringe area and so human settlement had a very insignificant evolution. This is considered as the phase of tiny and dispersed settlements.

Between 1996 and 2010, the average price of land was 3000 FCFA (5.45 USD) per square meter in the rural urban fringe and 12.00o (21.8 USD) in the purely urban area which was fast growing towards the North East. The major road had been constructed and several secondary and high schools managed by the public and private sectors had been created. There were already several private universities such as the National Polytechnic, Cameroon University of Science and Technology and The Saint Louis Higher Institute of Nursing which were all attracting human settlement in the area. The Young Sports Football Academy was created in Njenefor quarter.

Given the gentle undulating relief of the area, little human effort and less finance is needed for investment. Hazards like landslides and floods are not common. The municipality was serving as a gateway into Bamenda, the regional capital city of the North West region of Cameroon from three administrative divisions; Boyo, Ngoketunjia, Bui and Donga Mantung. It should be noted that migrants from these divisions prefer to reside along the stretch of road leading to their division of origin. There was a growing interest on land occupation during this period, thus a significant evolution of human settlement. The direction of the evolution was easily identified, a South West-North East direction along the major road. The rural urban fringe was gradually becoming urban while a new rural urban fringe was being created. This was the pre urbanization phase.

Between 2010 and 2015, the average price of land was 600oFCFA (10.9 USD) per square meter in the area which was a rural urban fringe between 1980 and 1995 and which has become almost fully urban. The average price of land in the core urban area of Bamenda III (Bayelle, Ntaghem, etc) is already at 12.0ooFCFA (21.8 USD) per square meter. In the newly created rural urban fringe, the price of land is 150oFCFA (2.72 USD) per square meter in Nzah village and in Mboung, Nkwenjang and Ketesoh quarters of Nkwen village. During this period Bamenda III continue to evolve in facilities and service provision such as the extension of water and electricity supply which are important pull facilities for human settlement. Settlement dynamics in this area during this period was manifested in the increase in the acquisition of land. The main cause was the creation of the University of Bamenda in Bambili, a semi urban area located 5 to 10 minutes' drive from the heart of Bamenda III. The University of Bamenda, the lone state own university in the North West region was created in 2011. Its creation attracted several stakeholders who prefer to reside in Bamenda III and commute daily to Bambili. Health service providers started clinic and pharmacy services, businessmen started the sales of building construction materials, day care centers, pre nursery, nursery and primary education centers were opened, three fuel pump stations were opened and A Catholic Private Hospital was created. Housing architecture evolve from horizontal to vertical with buildings of several floors. Though the price of land had increased, it had no negative effect on the human settlement dynamics. Densification is already taking place in the North East part of Bamenda III.

The major drivers for settlements dynamics in Bamenda III; constantly growing population, weak land tenure policy and the existence of multiple stakeholders of land development were supported by the sprawl or surface drivers; the price of land, communication potential, price of the land, access to facilities and services and less geographical risk to produce a very significant human settlement dynamics between 1996 and 2015 .

\subsection{Phases and manifestation of human settlement dynamics in Bamenda III municipality: densification and expansion}

Human settlement evolution in the Bamenda III municipality can be presented in three phases; the phase of tiny and dispersed settlement of 1989, the Preurbanization phase of 1999 and the current phase of 2015. Settlement densification and expansion took place in every phase in different areas.

a). The phase of tiny and dispersed settlements, 1989. During this period Bamenda III existed as part of the Bamenda City Council that made up the provincial capital of the former North West province, today the North West region. It was a purely rural area with a mother cluster situated at the South East made up of Bayelle, Sisia, Mugheb and Ntaghem quarters (Fig. 3). The only clustered human settlement areas were Bayelle, Sisia, Mugheb and Ntaghem quarters which was a continuum of the growing Bamenda urban area with the CBD located in Mankon. The rest of Bamenda III municipality had just some tiny but dispersed hamlets in the Futru area as a result of the presence of the Catholic church with a catholic primary school and in Menda as a result of a periodic market that brought buyers and sellers together once a week. There was no college, just a few primary schools in Ntaghem, Bayelle and Futru. Human settlement occupied just about 554 hectares of the total 6794 
hectares of the Bamenda III municipality. The main road was not paved. It was very muddy and almost non passable in the wet season and very dusty but passable in the dry season. The population was just about 20.00o inhabitants.

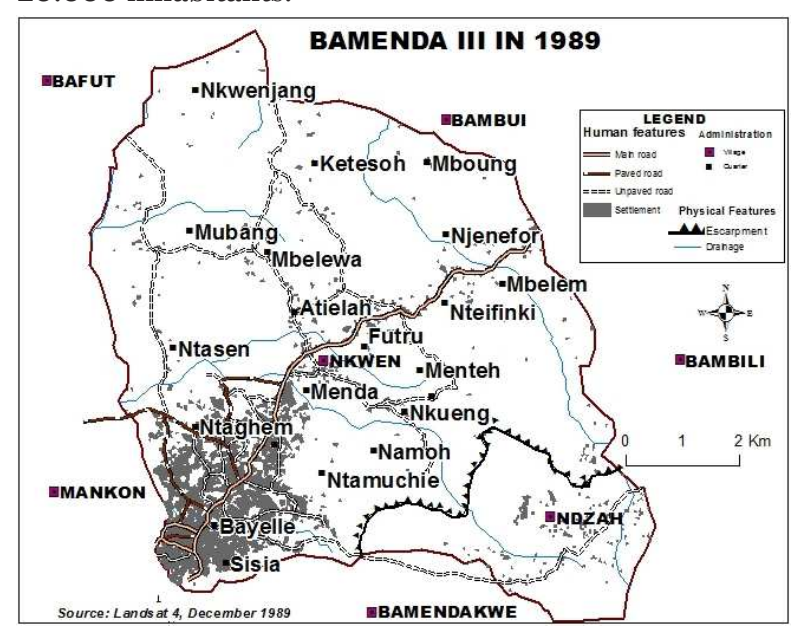

Fig. 3. Human settlement in the Bamenda III municipality in 1989 .

b). The Pre urbanization phase of 1999. The pre urbanization phase started in 1999 after the paving of the main road that cuts across Bamenda III municipality from the South West to the North East. The paving of this road led to the development of a form of linear human settlement on both sides of the road spreading from the urban nuclei at Mugheb, Bayelle, Ntaghem and Sisia. This is in accordance with the Bylunds model of 1960 which states that settlements expansion would take place along main transport arteries, and area close to the mother settlement were settled before more distance places. The population was about 50.000 inhabitants attracted by available cheap land for agriculture and the construction of residential and commercial houses. The St. Paul's Catholic College had been created as well as the Starlight College by the Catholic Church and a private entrepreneur. The Bamenda University of Science and Technology had been created in 1995 in Mbelem, Nkwen. A government secondary college had been created at Atielah quarters.
This justifies the extension of human settlement inwards to Mbelem and Atielah in the early 1990's. As earlier mentioned the creation of secondary, high schools and Universities has been a driving force for human settlement dynamism in Bamenda III municipality. The population had more than doubled and so was the total surface area covered by human settlement which also more than doubled to 1143 hectares. Farmland was gradually reducing from 2998 hectares in 1989 to 2778 hectares in 1999. The settlement dynamism continued to date.

c). The current phase of human settlement in Bamenda III municipality, 2015. In this analysis, it is observed that major changes have taken place in the Bamenda III municipality in the human settlement process. The South West-North East direction trend of human settlement evolution has been maintained with some growth poles created in the North West, towards the North and towards the East. The major change in 2007 was the creation of the Bamenda III Sub Division and the Bamenda municipality giving it a major administrative and municipal autonomy.

This led to the influx of state workers to work in the newly created sub divisional offices of the various ministries. It attracted also economic operators or entrepreneurs to the area to invest in various businesses especially the creation of schools, colleges and universities, and the construction of student hostels. A growth pole was started in Ntassen with the creation of the Presbyterian Secondary School in 2001. Another major growth pole was the creation of the National Polytechnic University in Njenefor in 2002. It should be noted that the creation of these educational centers has transformed these areas as it is the major force of attraction of human population. The population has increased to 150.000 inhabitants occupying 1986 hectares compared to 554 hectares 27 years ago. Farmland has reduced to 2485 hectares from 2998 hectares in 1989. Table 3 presents the land surface area changes in various land uses in Bamenda III Municipality in 2015.

Table 3. Land use surface area changes in Bamenda III municipality.

\begin{tabular}{|c|c|c|c|c|}
\hline Year & $\begin{array}{l}\text { Settlement } \\
\text { (ha) }\end{array}$ & $\begin{array}{l}\text { Farmland } \\
\text { (ha) }\end{array}$ & $\begin{array}{l}\text { Riparian forest } \\
\text { (ha) }\end{array}$ & $\begin{array}{l}\text { Grassland } \\
\text { (ha) }\end{array}$ \\
\hline 1989 & 554 & 2998 & 1282 & 1959 \\
\hline 1999 & 1143 & 2778 & 1045 & 1829 \\
\hline 2015 & 1986 & 2485 & 769 & 1554 \\
\hline Total land & 6794 & 6794 & 6794 & 6794 \\
\hline In Km square & & & & 67.94 \\
\hline
\end{tabular}

The spatial evolution of human settlement in 1999 and 2015 is shown in Figure 4. The dynamism in human settlement in Bamenda III municipality as observed in figures 3 and 4 show a constant densification and expansion in the process. In the mother human settlements of Sisia, Mugheb, Ntaghem and Bayelle, there is a full process of densification. Population increase and the anxiety to stay or carry out socio economic activities in the urban areas have led to the occupation of every piece of space for shelter, 
services or infrastructure networks. At the same time as the urban part of Bamenda III municipality is undergoing densification, the colonization of virgin lands was taking place in the rural areas. Obviously there was the need for new shelter, new services and new network infrastructure.

Table 4. Functional code table of functions dynamism in Bamenda III Municipality.

\begin{tabular}{|c|c|c|c|c|c|c|}
\hline & \multicolumn{3}{|c|}{ Bamenda III Municipality Urban } & \multicolumn{3}{|c|}{ Bamenda III Municipality rural } \\
\hline & 1989 & 1999 & 2015 & 1989 & 1999 & 2015 \\
\hline Education & Primary & $\begin{array}{l}\text { Nursery } \\
\text { Primary } \\
\text { Secondary }\end{array}$ & $\begin{array}{l}\text { Pre nursery } \\
\text { Primary } \\
\text { Secondary } \\
\text { University }\end{array}$ & Primary & $\begin{array}{l}\text { Primary } \\
\text { Secondary }\end{array}$ & $\begin{array}{l}\text { Pre nursery } \\
\text { Primary } \\
\text { Secondary } \\
\text { University }\end{array}$ \\
\hline $\begin{array}{l}\text { Health / } \\
\text { Medical } \\
\text { Services }\end{array}$ & Hospital & $\begin{array}{l}\text { Hospital } \\
\text { Maternity } \\
\text { Dispensary } \\
\text { Pharmacy }\end{array}$ & $\begin{array}{l}\text { Hospital } \\
\text { Maternity } \\
\text { Dispensary } \\
\text { Pharmacy }\end{array}$ & & Health Center & $\begin{array}{l}\text { Health Center } \\
\text { Pro Pharmacy }\end{array}$ \\
\hline Administrative & Customary court & Customary court & Customary court & $\begin{array}{l}\text { Customary } \\
\text { court }\end{array}$ & $\begin{array}{l}\text { Customary } \\
\text { court }\end{array}$ & $\begin{array}{l}\text { Local Government } \\
\text { Customary court } \\
\text { Ministries } \\
\text { Police Station } \\
\text { Gendarmerie }\end{array}$ \\
\hline Religion & $\begin{array}{l}\text { Churches } \\
\text { Mosques }\end{array}$ & Churches & $\begin{array}{l}\text { Churches } \\
\text { Mosques }\end{array}$ & $\begin{array}{l}\text { Churches } \\
\text { Mosques }\end{array}$ & $\begin{array}{l}\text { Churches } \\
\text { Mosques }\end{array}$ & $\begin{array}{l}\text { Churches } \\
\text { Mosques }\end{array}$ \\
\hline Economic & $\begin{array}{l}\text { Permanent market } \\
\text { Fuel Station } \\
\text { Trading shops }\end{array}$ & $\begin{array}{l}\text { Permanent market } \\
\text { Fuel Station } \\
\text { Trading shops } \\
\text { Printing/Publishing }\end{array}$ & $\begin{array}{l}\text { Permanent market } \\
\text { Fuel Station } \\
\text { Bank } \\
\text { Bakery } \\
\text { Trading shops } \\
\text { Printing/Publishing }\end{array}$ & $\begin{array}{l}\text { Periodic } \\
\text { Market }\end{array}$ & $\begin{array}{l}\text { Permanent } \\
\text { market } \\
\text { Trading shops } \\
\text { Slaughter } \\
\text { house }\end{array}$ & $\begin{array}{l}\text { Permanent market } \\
\text { Fuel Station } \\
\text { Money transfer } \\
\text { Trading shops } \\
\text { Slaughter house } \\
\text { Printing/Publishing }\end{array}$ \\
\hline $\begin{array}{l}\text { Social } \\
\text { Functions }\end{array}$ & $\begin{array}{l}\text { Electricity } \\
\text { Pipe borne water } \\
\text { Paved road }\end{array}$ & $\begin{array}{l}\text { Electricity } \\
\text { Pipe borne water } \\
\text { Paved road } \\
\text { Hotel } \\
\text { Telecommunication }\end{array}$ & $\begin{array}{l}\text { Radio station } \\
\text { Electricity } \\
\text { Pipe borne water } \\
\text { Paved road } \\
\text { Hotel } \\
\text { Telecommunication } \\
\text { Night club } \\
\text { Restaurant } \\
\text { Fire fighter }\end{array}$ & $\begin{array}{l}\text { Wells } \\
\text { Boreholes } \\
\text { Unpaved } \\
\text { road } \\
\text { Small } \\
\text { unpaved } \\
\text { roads }\end{array}$ & $\begin{array}{l}\text { Paved roads } \\
\text { Electricity } \\
\text { Wells } \\
\text { Boreholes }\end{array}$ & $\begin{array}{l}\text { Electricity } \\
\text { Pipe borne water } \\
\text { Paved road } \\
\text { Large unpaved roads } \\
\text { Football pitch } \\
\text { Hotel } \\
\text { Night club } \\
\text { Telecommunication }\end{array}$ \\
\hline
\end{tabular}

Source: Field survey, 2015/2016.

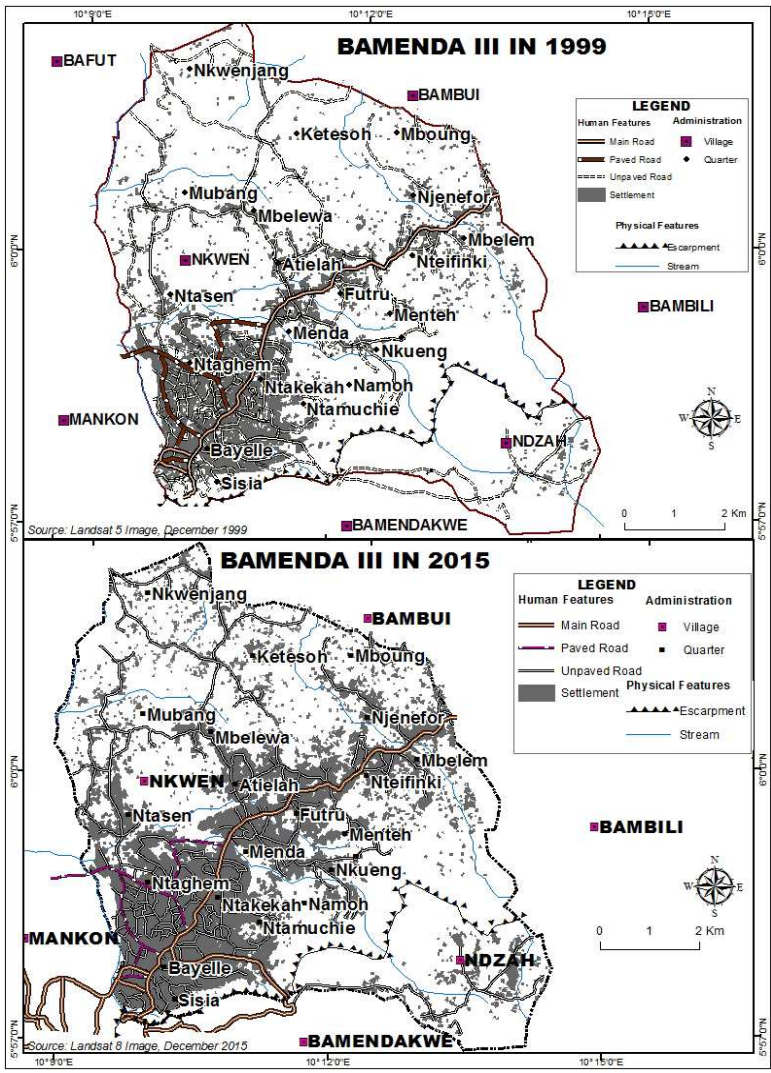

Fig. 4. Spatial evolution of Bamenda II in 1999 and 2015.
This expansion respected the preferred roadside occupation first, followed by an inward expansion around the early 2000's. The dynamism in shelter was accompanied by dynamism in services thus augmenting the functions provided by the Bamenda III municipality.

\subsection{Functions dynamics in Bamenda III municipality}

There has been great evolution in the functions offered by the Bamenda III municipality. The functional code table shows a clear dynamism over the several periods observed (Table 4). The increase in the population of the Bamenda III municpality was the main driving force towards human settlement. Human settlement dynamism was manisfested through the densification and expansion of shelter from the mother settlement in the urban area towards the rural settlement through expansion. The complete process was accompanied by a full dynamism in the functions offered by the Bamenda III municipality as shown on Table 3. In the education sector, the offering of university education is more in the rural than in the urban area. They offer common economic functions like fuel stations and permanent markets. 


\section{ANALYSIS OF SETTLEMENT DYNAMICS IN BAMENDA III MUNICIPALITY}

In Bamenda III like in other parts of Cameroon, there is land managed by customary owners like Nkwen village and Dzah village. There are private owned lands with land titles showing registration. There are State private owned lands registered for state institutions and the entire national land managed by the state. Three State institutions in Cameroon, MAETUR, the Mission for the Planning and Equipment of Rural and Urban lands, MAGZI, the Industrial Zones Development Agency and SIC, Cameroon Real Estate Corporation are all responsible to obtain land, plan and develop it for settlement construction, industries and low cost housing development. The Ministry of Housing and Urban Development and the Ministry of State Property, Surveys and Land Tenure all have the responsibility to ensure that settlement development is carried out in respect of the law. The municipalities like the Bamenda III Municipality, formerly under the Ministry of Territorial Administration and Decentralization and presently under the newly created Ministry of Decentralization and Local Development are managed by the local population and serve as a field operational institution to monitor settlement expansion in terms of planning and the respect of the rules and regulations as stipulated by the law.. With a rich legal and institutional framework, the government of Cameroon expects settlement dynamics to be orderly, formal and in respect of the law. But the actual expansion in Bamenda III is not appropriate and not as expected. The Impact of MAETUR, MAGZI and SIC are yet to be observed in Bamenda III. The land market is dominated by the customary owners who parcels them out and sells them without any development plan. Land is sold with simple conveyance since the owners have no land titles. They are demarcated with simple natural features like streams, trees, peace plant, unregistered pillars, thus the common disputes over boundary lines. This has given rise to an anarchical occupation and disorderly informal growth of settlements where roads respect the construction of houses rather than the reverse.

The scenario of unplanned human settlement dynamics is not found only Bamenda III Municipality. It exists in other parts of Cameroon. Even Yaoundé and Douala, the administrative and economic capitals are not left out. In Latin America and the Caribbean, countries like Argentina, Uruguay, Venezuela, Chile, Colombia and Costa Rica all have unplanned settlements with efforts made for their upgrading. South Africa, Nigeria and China are also found amongst the countries with more informal than formal settlements. It is therefore similar to other African countries and cities. The best situation would have been one where there are more planned than unplanned settlements. The development of slums is the outcome of unplanned human settlement over a long period of time.

The consequences shall be poor or no water and electricity supply, very low quality service provision for health and education leading to easy illnesses and disease spread, political and social exclusion of the population in such areas, disaster prone with less interconnectivity and accessibility, urban criminality, etc. To improve on interconnectivity and accessibility, the government of Cameroon in partnership with the World Bank in 2013 opted for urban renewal in Bamenda II Municipality, the core of Bamenda City. Houses were destroyed to open up new roads and enlarge the existing small roads. Sisia quarter, the oldest quarter in Bamenda III located at the South West is already a slum. In 2013, studies for a participatory slum upgrading programme was funded by UN/HABITAT in partnership with the Bamenda City Council, the Special Council Support fund for Mutual Assistance and the Bamenda III Municipality. Upgrading elements include, town planning, restructuring and resettlement documents to be provided, drainage construction, road construction, potable water supply, health centers construction, primary and nursery schools construction, waste and hygiene system provision, land tenure security improvement and the building of capacities of stakeholders especially the local population. The upgrading is estimated to cost $1,624,471,465$ FCFA. (893,459,305,750 USD). Upgrading, which is expensive and whose outcome will never be equal to a wellplanned settlement expansion would have been avoided if settlement dynamics was planned in Sisia quarter. Such a situation must be avoided in other areas of Bamenda III, in Cameroon and globally.

\section{CONCLUSION}

Bamenda III Municipality was an integral part of the Bamenda City Council up to 2007 when it was raised to an independent administrative and municipal unit.

Settlement dynamics is a reality in the study area and several drivers' accounts for that. The evolution in the drivers between 1989 and 2015 permits the identification of three phases in the manifestation of the dynamics. Three major drivers were identified; a constantly growing population, a weak land tenure policy with very little control mechanisms for settlement construction and the existence of multiple stakeholders in land development. Added to these major drivers are surface drivers or sprawl drivers which include the price of land, communication potentials, access to facilities and services and geographical risks. The constantly increasing human population was accompanied by the putting in place of 
social and technical infrastructures which serve as a spring board for settlement dynamism. Roads, hospitals, schools, universities and several others were put in place. Interconnectivity and accessibility improved as the population grew and as technical infrastructures like roads and bridges were constructed. A gentle undulating topography, easy to access and for construction attracted many people to the area couple by an evolution in the price of land at the reach of the average citizen.

Three phases of human settlement evolution were and two manifestations identified. A phase of tiny and dispersed human settlement was identified in 1989, a pre-urbanization phase of 1999 and the current phase since 2015. Human settlement dynamics show a constant expansion and densification in the process. In the first phase, there was a single cluster in the South East where human settlement occupied just about 554 hectares of the total 6794 hectares of the Bamenda III municipality. The paving of the major road after 1999 led to the beginning of a human settlement evolution process with a South West-North East direction. The total surface area covered by human settlement more than doubled to 1143 hectares. In the third phase, human settlement covers 1986 hectares as a result of increase in population and services. While expansion was following a South West-North East direction to new areas like Futru, Nteifinki, Manda, Mbelewa, Atielah and Ntassen, the mother settlements of Sisia, Mugheb, Ntaghem and Bayelle were undergoing densification. Gardens and small farmlands are being occupied by settlements and other activities.

The functional code table show a clear dynamism in functions linked to human settlements between 1989 and 2015 in several sectors; education, health, administration, religion, economic and social functions. It should be noted that the functions offered by an area is an important factor in settlement evolution. An increase in population must be accompanied by an increase in the functions offered. This is real in Bamenda III. In 2007, the Bamenda III Municipality was created. This was a great uplift in terms of administration and municipal services. No more commuting to the city center for administrative or municipal services. The paving of the major road linking Bamenda III to four administrative divisions made it a gateway into Bamenda city. The people from these divisions prefer to reside in Bamenda III for easy access to their divisions of origin. The construction of the Catholic Hospital, the Futru Catholic Church, several private universities and a State University in Bambili in 2011 all had a positive impact on settlement dynamics in the study area. The present trend show clearly that the process of settlement dynamics in Bamenda III will continue. Newly occupied areas shall in future be densified and new areas again conquered. There are formal and informal human settlements in
Bamenda III. The existing legal and institutional framework for land tenure is weak with implementation lapses leading to a very low proportion of the population acquiring Building permits and an eventual land certificate for their settlements to be formal or authorized. The weaknesses in implementation and control are such that for every ten settlements only one is authorized. The study suggests a reinforcement of control of settlement dynamics in Bamenda III Municipality by the institutions responsible for that. There is need for strong institutions. There are several challenges in upgrading informal settlements and these should be avoided. There should be a good concerted action between the public sector, the private entrepreneurs and the local population in order to improve on formal settlements, since informal settlements dominate in the study area.

\section{REFERENCES}

[1] Sarkar, A. (2010), The Analysis of Human Settlement Patterns Using RS and GIS in the Plains of West Bengal. In: eTraverse, the On-Line Indian Journal of Spatial Science. Vol 1, No 1, pp. 1-16. Available at: http://indiansss.org/pdf/pdfset-1/issue set-3/Art_o01.pdf.

[2] Whynne-Hammond, C. (1985), Elements of Human Geography. Second Edition. Bell and Hyman Ltd.

[3] *** ThessISSMUN (2016), Second Committee of the General Assembly. Topic Area B "Human Settlement and Urban Development: Implementation of the Habitat Agenda and Proposals for the New Urban Agenda. University of Macedonia, Greece.

[4] United Nation Centre for Human Settlement (2006), Cities in a Globalizing World: Global Report on Human Settlements. Earthscan, London and Sterling.. Available online at: http://www.un.org/en/ events/pastevents/pdfs/Cities_in_a_globalizing_world 2001.pdf

[5] Winchester, L. (2005), Sustainable Human Settlement Development in Latin America and the Caribbean. Report of the Sustainable Development and Human Settlement Division. United Nation Publication, Santiago, Chile. Serie: Medio Ambiente Y Desarrollo. Available online at: https://www.unisdr. org/files/9219_lcl2287i.pdf.

[6] Durand-Lasserve, A., Tribillon, J-F. (2001), Coping with Illegality in Human Settlements in Developing Countries. A contribution to the ESF/NAERUS Workshop, Leuven and Brussels, Belgium, 2326 May, 2001. Available online at: http://www.ucl. ac.uk/dpu-projects/drivers_urb_change/urb_economy /pdf_infor_econo/ESFN_AERUS_Lasserve_Tribillon. pdf.

[7] Ziblim, A. (2013), The Dynamics of Informal Settlement Upgrading in South Africa: Legislative and 
Policy Context, Problems, Tensions and Contradictions. A Study Commissioned by Habitat for Humanity International/EMEA Office, Oratislava, Slovakia. Doi.org/10.1080/09709274.2007.11906026. Available online at: http://globalhousingindicators .org/sites/globalhousingindicators.org/files/The\%20Dy namics\%20of\%2oInformal\%2oSettlements\%2oUpgradi ng\%20in\%20South\%20Africa.pdf

[8] Linard Gilbert, C. M., Snow, R. W., Noor, A. M., Tatem, A. J. (2014), Population Distribution, Settlements Patterns and Accessibility across Africa in 2010. In: PLoS, vol. 7, issue 2, pp. 1-8. Doi.org/10.137/journal.pone 0031743. Available online at: http://journals.plos.org/plosone/article/file?id $=10.1371 /$ journal. pone $.0031743 \&$ type $=$ printable

[9] Omofonmwan, S. I., Kadiri, M. A. (2007), Evolution and Spread of Settlements in the Esan Area of Edo State. In: Journal of Human Ecology 22(3) pp. 227-233. Doi.org/10.1080/09709274.2007.11906026.

[10] Ahmed, Y. A. (2009), Settlements Pattern and Functional Distribution in an Emerging Community: a case study of a Local Government Area of Kwara State, Nigeria. In: The Social Sciences, Medwell Publishing 4(3), pp. 256-263. ISSN 1818-5800. Available online at: http://docsdrive.com/pdfs/ medwelljournals/sscience/2009/256-263.pdf.

[11] Ibuma, B., Wachukwu, F. C. (2015), Settlement Dynamics in the Northern Fringes of Port Harcourt Metropolis. In: International Journals of Scientific and Technological Research. vol. 4, issue 05, pp34-43. ISSN 2277-8616. Available online at: http://www.ijstr.org /final-print/may2015/Settlement-Dynamics-In-TheNorthern-Fringes-Of-Port-Harcourt-Metropolis.pdf.
[12] Chen, M., Ye, C. (2014), Differences in Patterns and Driving Forces between Urban and Rural Settlements in the Coastal region of Ningbo, China. In : Sustainability, 6, pp. 1848-1867. Doi: 10,3390/ su6041848. Available online at: http://www. mdpi.com/2071-1050/6/4/1848.

[13] Du Plessis, C., Landman, K. (2002), Sustainability Analysis of Human Settlements in South Africa. CSIR Building and Construction Technology Programme for Sustainable Human Settlement, Pretoria.

[14] ECOAfrica (2015), Limpopo Environmental Outlook Report-1 $1^{\text {st }}$ Draft. Chapter 6: Human Settlements for the Limpopo Province, South Africa. Available online at: http://www.ecoafrica.co.za/sites/ default/files/project_resources/8\%20LEO\%201st\%20 DRAFT\%20Chapter\%206\%20Human\%20Settlements \%2020151209-2.pdf

[15] Costa, A., Marchettini, N., Fachini, A. (2004), Developing the Urban Metabolism Approach into a New Urban Metabolic model. In: The Sustainable City III, Urban Regeneration and Sustainability. N. Marchettini, C. A. Brebia, E. Tiezzi and L. C. Wadhwa (Editors), Doi: 10.2495/SC040041. Pp. 32-40. Available online at: https://www.witpress.com/Secure/elibrary /papers/SCo4/SC04004FU.pdf

[16] Bamenda III Council (2010), Bamenda III Council Development Plan (Main Document), Nkwen, Bamenda.

[17] Bamenda City Council (2015), Records of Building Permits Issued 2008-2015.

[18] Bamenda III Sub Divisional Office (2015), Archives of Land Certificates Issued From 2008-2015. 